\title{
Talking Europe, Using Europe: The EU and Parliamentary Competition in Italy and Spain (1986-2006)
}

\author{
FABIO GARCÍA LUPATO
}

The analysis of how the European Union (EU) affects domestic political competition and political parties has mainly been centred on elections, whereas studies on parliaments have focused more on institutional adaptation. However, parliaments also provide forums for debating alternative domestic and EU policies. This study examines how Europe is used in parliamentary competition in Italy and Spain by analysing party discourses in investiture and budget debates. Covering two decades (1986-2006), the study investigates whether or not the EU has gained importance over time in the way parties use European policies, the evolution of party positions towards the EU and, more generally, the consequences of integration for party policies and discourse.

Keywords: Italy; Spain; parliaments; parties; European Union; debates.

\section{Introduction}

The impact of the European Union (EU) on domestic politics has been studied in different and complementary ways. Regarding political parties and political competition, the analyses have normally been centred on the electoral arena, while studies on parliaments have focused mainly on institutional adaptation. Analysing how parties compete in the parliamentary arena can hence provide new insights into the way the EU and its policies are interiorised at the domestic level.

Without denying the importance of elections, parliamentary competition provides, in a certain way, a far more realistic, clear and constant position of political parties. It is more realistic because parties have to present and explain specific policies, to defend their ideas and position on issues that are sometimes impossible to downplay. Equally, as the debates almost always include a final vote, parties have to explain the direction of their vote in a clear way. Finally, this position has to be sustained over a certain period of time, being therefore more constant. Consequently, the analysis of the parliamentary arena provides different insights on how parties and their leaders react to, interiorise and use Europe in domestic political competition. Moreover, it can help to overcome some of the problems that arise if we focus on the electoral arena. Notably, three main problems are important: declared salience, because parties emphasise positive and cohesive issues during elections; dissent, which is minimised within the party during campaigns; and timing, as elections are held only every four or five

The Journal of Legislative Studies, 2014

Vol. 20, No. 1, pp. 29-45, http://dx.doi.org/10.1080/13572334.2013.871483

(C) 2014 Taylor \& Francis 
years, which is especially relevant in a time-sensitive issue such as European integration (Marks, Hooghe, Steenbergen, \& Bakker, 2007).

This study analyses the importance and usages parties make of the European context and its policies in parliamentary investiture and budget debates. The former presents the government programme for the legislature, while the latter concerns what is probably the most important law approved by the parliament each year and makes reference to economic policy. Both debates have a very high salience in public opinion and the media. A comparative research design is used by analysing Italy and Spain, and 13 parties over a broad time period (1986-2006), allowing a synchronic and diachronic analysis and a wide range of cases for analysing parties' usage of Europe. ${ }^{1}$

The next section contains a brief account of the notion of usage, after which case selection and methodology are dealt with. Following this, the empirical analysis will be done in two steps, the first focusing on the importance of Europe in both types of debate and the second on the usages of Europe. The final section discusses the findings.

\section{Political Competition, Parties and the EU: New Insights from a Different Perspective}

The notion of usage is crucial for the analysis in this study and can be defined as 'practices and political interactions which adjust and redefine themselves by seizing the European Union as a set of opportunities, be they institutional, ideological, political or organisational' (Jacquot \& Woll, 2003, p. 4). Usage has to be intentional because 'whatever might be the nature of specific opportunity ... actors need to seize them in order to transform them into political practices. The whole process of transforming resources or constraints into political practices constitutes a usage' (2003, p. 4). As a result, 'political usage describes the mediation done by an actor to transform a material or immaterial resource provided by the European institutions into a political action' (2003, p. 6).

Furthermore, this approach considers that the EU and its policies have different consequences depending on domestic context and institutional factors. This is a key difference: the context is not exogenous but rather endogenous, where parties may have different perceptions on the consequences of specific European issues (Garrett, 1998; Hay \& Rosamond, 2002; Hay \& Smith, 2005). Institutional, economic, social and cultural factors play a role in the conceptualisation of European opportunities and constraints. That is why 'there is no single unifying discourse of globalisation and/or European integration; rather such notions are appealed to in different ways in different contexts. This highlights the need to map and compare the appeals to discourses of globalisation and European integration in different national settings' (Hay \& Smith, 2005, p. 125). Thus, European integration cannot be considered as an objective and uncontested exogenous process. 
Based on this definition and the different interpretation and perception of opportunities and constraints offered by the European context, some possible usages of Europe have been selected. Europe can be conceptualised as an incentive or constraint for action, for legitimising some policy options, for evaluating some EU policies positively or negatively or simply for using Europe as a frame of reference to compare policy performance. Equally, and as EU policies are not ideologically neutral, different parties with different ideologies, in government or in opposition, may use Europe and its policies in different ways and, so, the politicisation of Europe and its policies can play a significant role in parliamentary competition.

One final aspect deals with how European integration may affect domestic party systems. On the one hand, direct impacts assume that domestic party systems change as a result of EU pressure, creating a new cleavage and thus new parties. However, in this sense, European integration has had little if any impact (Mair, 2000). On the other hand, scholars have also recognised the importance of indirect impacts, that is, a more subtle way by which the EU may affect domestic political competition, such as the reduction of policy decidability or the disempowerment of elections and voters as many of the issues discussed at the national level have already been agreed upon at the European level (Bartolini, 2005; Mair, 2000). The analysis of the usages of Europe can help to track down some of these indirect impacts.

From this discussion and from previous research we can argue that the interiorisation of the EU depends on different, although interrelated, factors, such as government/opposition status, the nature of the party system and domestic cleavages, and party ideology or position towards European integration. We can thus elaborate the following hypotheses:

H1: Owing to the deepening of European integration between 1986 and 2000, the EU's importance and relevance in domestic debates should increase over time.

H2: Domestic political and economic contexts affect the way European opportunities and constraints are perceived. In countries with more stable governments or high economic growth, the EU should be less contested than in countries with governmental crisis or non-existent growth. H3: Governing parties present more positive usages than parties in opposition. In turn, opposition parties can present negative accounts of European policies and use the EU as another tool for criticising the government. H4: Larger parties with vote-seeking strategies use the EU in a more positive way than smaller and policy-seeking parties. Furthermore, in mainly pro-European countries, larger parties tend to be pro-European whereas smaller ones present more critical positions on integration.

H5: The EU's specific processes or policies can open new structures of opportunity in domestic political competition. In this sense, the indirect impacts of the EU gain importance. 


\section{Case Selection and Methodology}

Four aspects are especially relevant in this analysis: country, parties, debates, and time span. Regarding country selection, Italy and Spain joined the EU in different periods and some scholars agree that the longer a country is an EU member, the more Europeanised it should be (see, for example, Pennings, 2006). They are the two biggest southern European countries, with broadly similar European interests and where Europe has been traditionally conceptualised as an opportunity for modernisation. The countries differ regarding economic performance, with Spain considered a more successful country whereas Italy experienced a period of low or non-existent growth during the period of analysis. ${ }^{2}$ Their party systems are different, with diverse institutional settings, dynamics and effective number of parties. To cover the broadest examples, 13 parties have been selected, including both government and opposition parties, vote- and policy-seeking parties and parties with different ideological profiles and positions towards integration (Table 1). Whereas in Spain there are only one-party governments, in Italy governments are formed by electoral coalitions that also include, as a rule, Eurosceptic parties.

Two debates are analysed, investiture and budget debates. Owing to their relevance, interventions are usually made by the party leader. For this analysis, the first intervention of each party's representative has been selected and, in the Italian case, the vote declarations of the most prominent political leaders. Each intervention comprises the unit of analysis and has been codified following a specific codebook that includes different variables (see later). Owing to the purpose of this study, the time span is also relevant. As I want to study the evolution and interiorisation of the EU and its policies, the Maastricht Treaty is considered as a critical juncture in European integration. Hence, the selection of

Table 1: The Selection of Parties and Parliamentary Debates

\begin{tabular}{|c|c|c|}
\hline Parties & Italy & Spain \\
\hline Left & Rifondazione Communista (RC) & Izquierda Unida (IU) \\
\hline Centre-left & Democratici di Sinistra (DS) & $\begin{array}{l}\text { Partido Socialista Obrero Español } \\
\quad \text { (PSOE) }\end{array}$ \\
\hline Centre & $\begin{array}{l}\text { Democrazia Cristiana (DC), La } \\
\quad \text { Margherita }\end{array}$ & \\
\hline Centre-right & Forza Italia $(\mathrm{FI})$ & Partido Popular (PP) \\
\hline Right & Alleanza Nazionale (AN) & \\
\hline Ethno-regionalist & Lega Nord (LN) & $\begin{array}{l}\text { Convergència i Unió (CIU), Partido } \\
\text { Nacionalista Vasco (PNV) }\end{array}$ \\
\hline \multicolumn{3}{|c|}{ Parliamentary debates (number of debates analysed) } \\
\hline $\begin{array}{l}\text { Investiture debates } \\
\quad \text { (years) }\end{array}$ & $\begin{array}{l}91 \text { (1986, 1989, 1993, 1996, 2000, } \\
\text { 2004) }\end{array}$ & $\begin{array}{l}30(1987,1988,1989,1991,1992 \\
\begin{array}{l}1994,1995,1996,1998,1999 \\
2000,2001,2006)\end{array}\end{array}$ \\
\hline $\begin{array}{l}\text { Budget debates } \\
\quad \text { (years) }\end{array}$ & 108 (Yearly from 1990 to 2006) & 80 (Yearly from 1990 to 2006) \\
\hline
\end{tabular}


investiture debates starts in 1986 for Spain and 1987 for Italy, while the analysed budget debates cover a period from 1990 to 2006.

This leads to the final aspect regarding methodology. A specific codebook has been built to track down different usages of Europe in domestic debates. On the one hand, it provides structural information (party, year, government status, party family). On the other hand, the following specific variables and usages were selected: (a) importance of Europe, that is, if Europe is important or not in each intervention; (b) impact of Europe on domestic politics, where specific EU policy outcomes can be considered as opportunities (with positive domestic consequences), constraints (with negative ones), mixed accounts, and no references (no mentions or usages are made); (c) domestic action, implying that the European context and debates can be conceived as incentives (for helping to foster domestic action), constraints (representing different limitations for domestic political action), mixed accounts, or no references; (d) legitimation, with or without mention of Europe, that legitimises political action (or inaction) or that shows the importance of implementing a certain policy; and finally (e) evaluation of European policies, where leaders evaluate EU policies as either positive (stressing the benefits of certain EU policies for the country), or negative (emphasising the negative impacts of EU policies for domestic interests), use mixed accounts or make no references.

\section{The Importance of Europe in Investiture and Budget Debates}

The first step of the analysis starts with the importance of Europe in the debates. Figure 1 provides data on the relevance of Europe in domestic debates highlighting

Figure 1: Importance of Europe in Investiture and Budget Debates

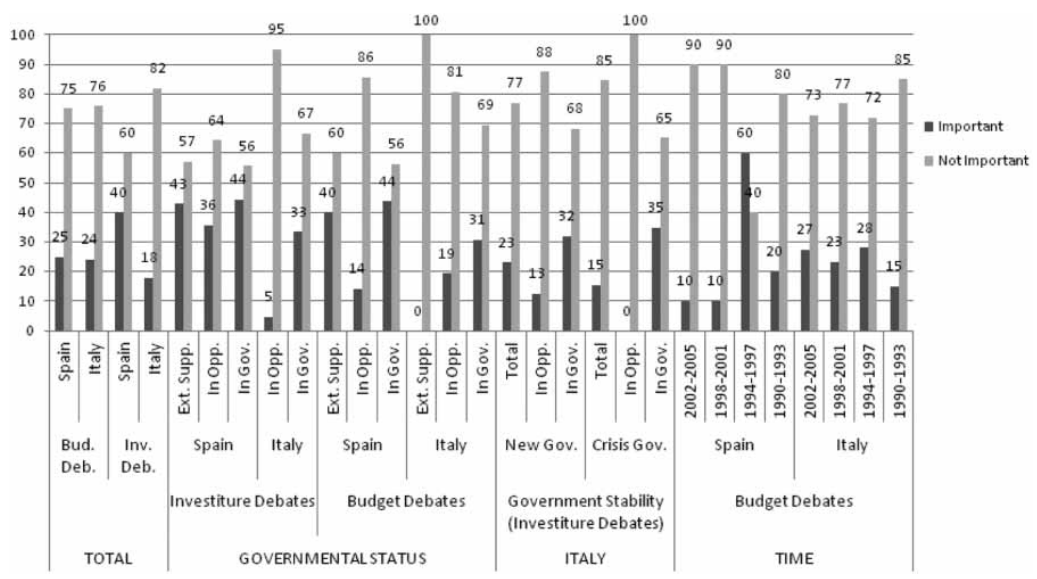

Note: All the data, in this and the following figures, present the percentage of interventions that are included in each category. 
certain variables: the difference between countries and debates, the relevance of governmental status and the importance of the timing of European integration.

We can observe the varying importance of Europe depending on the country and the debates. Even though Italy joined the EU long before Spain, Europe is, generally speaking, more important in the latter, especially regarding investiture debates (Europe is important in 40 per cent of the Spanish interventions but only in 18 per cent in Italy). Meanwhile, the importance in budget debates is similar in both countries (25 per cent and 24 per cent for Spain and Italy, respectively).

What explains this huge difference regarding investiture debates? The key factor is governmental strength and stability, because Europe and its policies are much more relevant in debates held after elections than in those held in the middle of the legislature, after a governmental crisis. Spain is characterised by strong governments whereas Italy, with its weakly institutionalised parties and electoral coalitions (a de facto two-party system), has less cohesive parties and less stable governments. Consequently, those investiture debates held after a governmental crisis, which normally include new governmental coalitions, are focused on the new government's legitimacy. In Berlusconi's (1998) own words, in the investiture debate of the 1998 centre-left government led by D'Alema: 'a government that is born not from the votes but from the fear of the vote, does not have democratic legitimacy, and can be defined just as the usual cheat.' ${ }^{3}$ The tendency for opposition parties is thus to focus on domestic factors and to downplay the importance of specific policies. In this case, the relevance of the EU disappears (0 per cent of interventions where Europe is important).

The incentives are different, however, for the new government. As shown by the data, the importance of Europe in government interventions is higher in this situation, rising to 35 per cent, 11 per cent higher than the mean importance of the EU in these debates. Contrary to opposition parties, cabinet parties use the EU for legitimising their incumbency. As D'Alema (1998) (Democratici di Sinistra [DS]) claimed in his programmatic declaration in the 1998 investiture debate:

I have never thought that the alternative advocated with strength by the opposition of Polo della Libertà, to call new elections, was acceptable ... But in the current Italian situation it is not convenient. Not because of formal prejudices, but for concrete and substantial reasons, starting with a fundamental one: new elections, as it is known, would have prevented approving a new budget law ... with negative repercussions not just on our country's image and credit but also, in a period in which the introduction of the euro is approaching, for the concrete interests of millions of Italians. This fundamental worry...h has pushed for an alternative and political solution, as an act of responsibility towards our country and its interests. (D’Alema, 1998, p. 7)

This leads directly to governmental status, which is the second important factor for explaining the role of the EU. Governing parties in both countries and in both 
debates accord Europe a higher importance than opposition parties. On the one hand, European integration is relevant as an issue per se. As Felipe González (1993) claimed in his 1993 investiture debate:

the programmatic offer that I present is centred along four main axes: the first one, to overcome the economic crisis and to drive forward the economy; the second, the democratic impulse; the third, regional development; the fourth, foreign policy and the impulse towards the European Union. (González, 1993, p. 2)

This issue is common to all governmental parties, as the $\mathrm{EU}$ will be a relevant aspect of their work. Furthermore, the EU is used for justifying their domestic actions, because they play a key role at the European level, while opposition parties are less active and less well-represented in key European institutions, making their strategy and discourse more nationally based.

The data also show the importance of timing. The period under analysis includes the discussion, adoption and implementation of Economic and Monetary Union (EMU) (1990-93, 1994-97 and 1998-2001, respectively) as well as the adoption of the euro (2002). During the adoption period (1994-97), the reforms needed for adapting to the Maastricht criteria necessitated unpopular decisions. Thus, we should expect a high importance of Europe during EMU's implementation. As Figure 1 shows, the importance of Europe in budget debates is indeed higher in 1994-97 (60 per cent in Spain and 28 per cent in Italy). EMU played a key role, especially for government parties, as they had to implement difficult policies, resulting not only from European opportunities but also from constraints, in a short period of time. Spain and Italy differ in the importance attributed to Europe after the introduction of the euro. While the EU's saliency sharply declined in Spain (10 per cent importance in 2002-5), in Italy its importance was sustained over time and even increased in the last period, almost to the levels of 1994-97.

What explains this divergence? As argued above, economic performance varied greatly between the two countries. Whereas Spain adapted to the euro during a period of sustained economic growth, the Italian economy was characterised by high public debt and slow economic growth. ${ }^{4}$ This helps to explain why the salience of the EMU issue declined in Spain, while it grew in Italy. Perception of political and economic European constraints applied not only to opposition parties in Italy, but also to governmental ones, as they were forced to accept suboptimal performances at the domestic level (Cotta, 2005), and made the European issue relevant for parliamentary discussion.

\section{Using Europe in Domestic Debates}

Positive or Negative Usages?

Both countries present a positive conceptualisation of the EU as fostering political action or as an incentive for the adoption of certain policies. This is consistent 
Figure 2: Impact and Domestic Action and Reaction to Europe

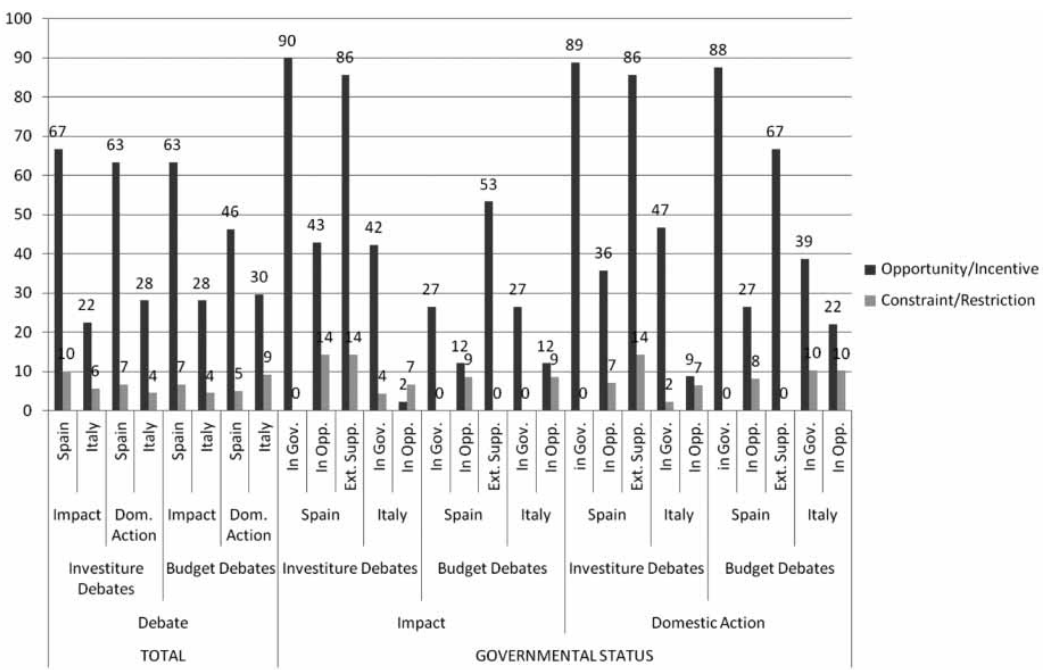

Notes: The two categories do not total 100 per cent. For clarity in the presentation of the data, 'mixed' and 'no reference' categories have been omitted. Most of the missing data belong to the 'no reference' category. In just two cases (in budget debates - in government in both Italy and Spain) the percentage of the 'mixed' category is over 10 per cent. For impact of Europe, the classification is opportunity or constraint. Meanwhile, for the usage of domestic action and restriction, the classification is incentive for action and restriction.

with their positive attitude towards European integration. As Figures 2-4 show, usages of Europe are mainly positive, while we find fairly few negative accounts. Europe is conceptualised as an opportunity (67 and 63 per cent of interventions in investiture and budget debates in Spain and 22 and 28 per cent in Italy) rather than as a constraint (10 and 7 per cent in Spain, 6 and 4 per cent in Italy, respectively). Similarly, Europe is internalised as an incentive for domestic political action (63 and 46 per cent in Spain, 28 and 30 per cent in Italy) and EU policies are conceived as a source for legitimising certain policy preferences in both investiture and budget debates (60 and 50 per cent in Spain, and 34 and 31 per cent in Italy).

In addition, the evaluation of European policies at the domestic level is mainly positive (60 and 39 per cent in investiture and budget debates in Spain, and 22 and 17 per cent in Italy), while negative evaluations are rare. Owing to the higher importance of Europe in the Spanish case, these usages are higher than in Italy. Not surprisingly, because of the pro-European position of most political parties, negative usages are less relevant. However, a more in-depth analysis qualifies this general picture, showing the increasing relevance of negative, and especially mixed, accounts of the effects of European policies on domestic competition. This is true for opposition parties, but, especially in Italy, governing parties are also starting to criticise some European outcomes and limitations. 
Figure 3: Europe as Legitimation

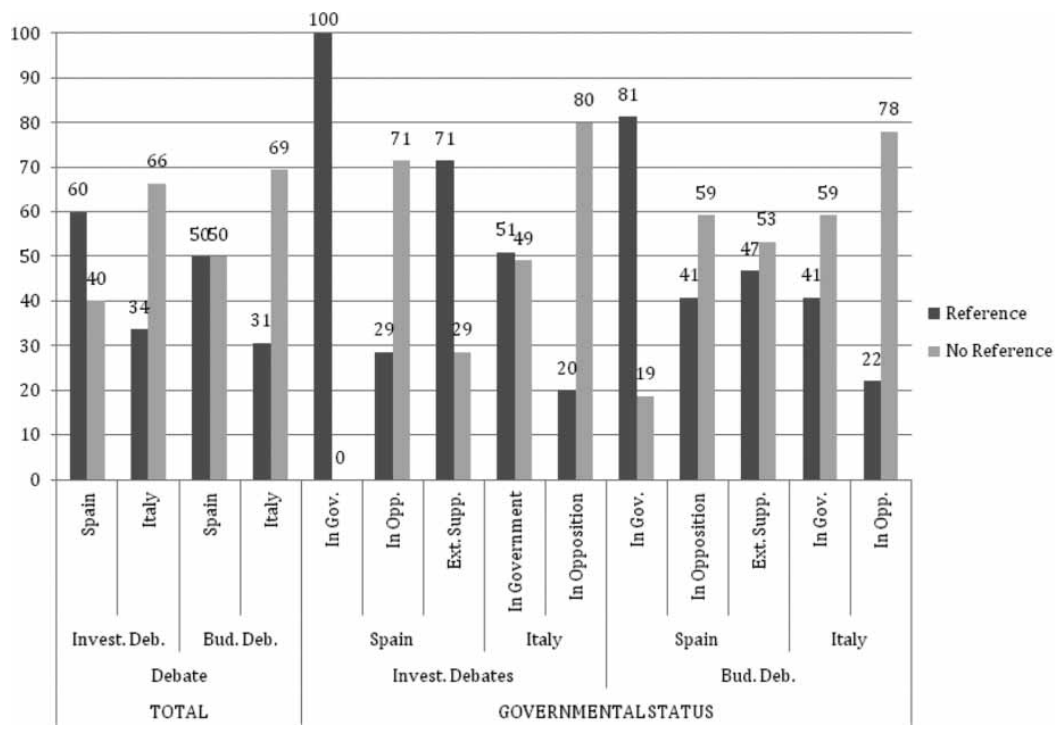

Government Status and the Perception of European Opportunities

Governmental parties put more emphasis on the opportunities derived from the EU (90 and 27 per cent in investiture and budget debates in Spain, and 42 and 27 per cent in Italy) and, even more interestingly, no negative perceptions are

Figure 4: Evaluation of European Policies

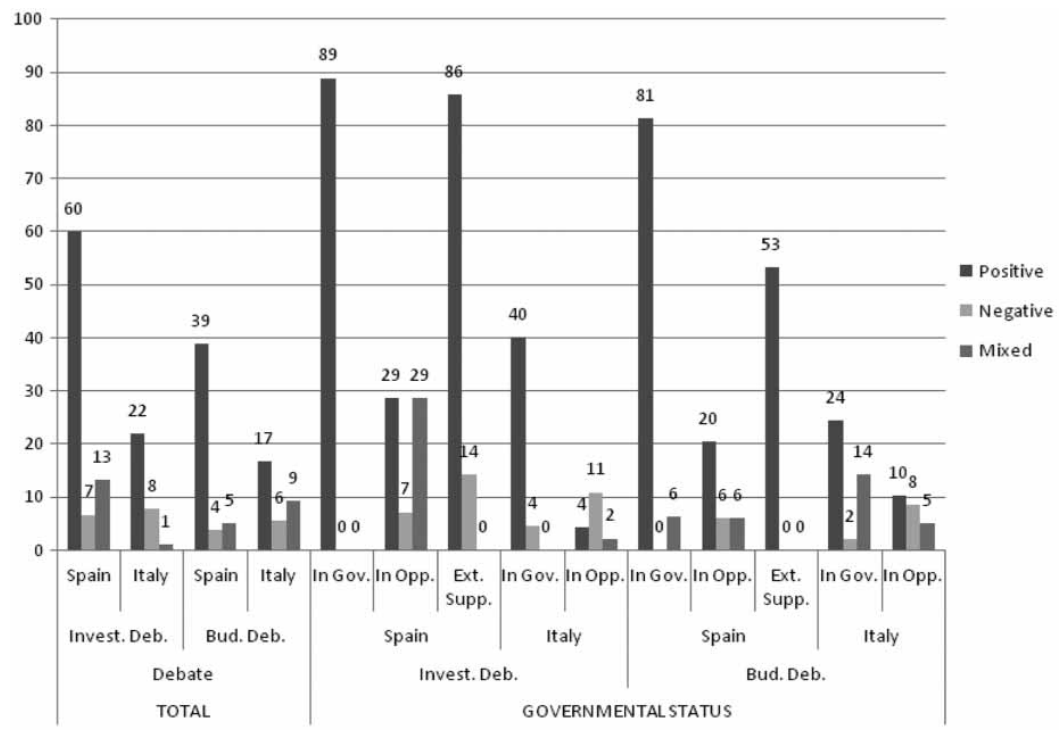


present (Figure 2). This positive position is reinforced by the widespread use of Europe as a source for legitimising policy decisions. This is especially clear in the Spanish case (in investiture and budget debates, with 60 and 50 per cent, respectively) and more so in governmental parties (100 per cent of cases in Spain and 51 per cent in Italy in investiture debates); although we can observe an important difference regarding budget debates (81 per cent in Spain but just 41 per cent in Italy).

The logic seems clear as governments are part of the European consensus and discuss and approve all European regulations. Equally, governmental parties have more information on EU issues, implying a better knowledge of the European process than opposition parties (Raunio, 2002). Consequently, it would be very difficult to vote for a European law and then reject it at home. This would imply a lack of credibility both at the domestic level as well as at the European level. Thus, EU regulations are conceived as positive, fostering domestic action with legitimating effects. Therefore, opposition to European regulations is mainly left to opposition parties, which monopolise the negative perceptions of European outcomes. However, we can observe a significant difference between Spain, where just a minority of interventions criticise the EU, and Italy, where criticism is much more evident in both debates. Another interesting aspect is shown by the positive conceptualisation of Europe by the parties supporting the government in Spain, especially the Partido Nacionalista Vasco (PNV) and the Convergència $i$ Unió (CIU). Does Europe play a role in explaining these parties' support of the government? Which parties criticise Europe and in what ways? And, even more importantly, are negative perceptions of Europe evolving from the politics of opposition (Sitter, 2002) to parties in government? The next section deals with these questions.

\section{Party Ideology and Position in the Party System}

Regarding Spain, we can observe that all parties analysed, except the United Left, present positive usages and, furthermore, do not, with few exceptions, have negative usages. Whether in government, in opposition, or acting as external supporters, negative accounts are not present. In the two vote-seeking parties, Partido Popular (PP) and Partido Socialista Obrero Español (PSOE), Europe is used for legitimising their policy options and for stressing the positive impacts and incentives for action that EU policies imply. Indeed, they do not present any negative perception of Europe, either in government or in opposition. ${ }^{5}$ Equally, CIU and PNV have played an active role acting as external supporters for the socialist and conservative governments. ${ }^{6}$ The data show the positive usages of external supporters to the government, ${ }^{7}$ and indeed, Europe provided an excellent narrative for justifying their support. In the 1995 budget debate, when the PSOE was unable to pass the new budget law, the CIU's speaker was clear: 
We understand, Mr Minister, and we share your demands for 1996 not to be a lost year in the process towards the EMU. It is true that on this year depends, in a good measure, the fact that Spain may be able to join in 1999 the third phase of the monetary union. But, do you really think, Mr Minister, that you have to remind us of that, of that powerful reason and against our parliamentary custom ... we have supported your government's budget during the last two years? (Molins, 1995, p. 9522)

Using similar terms, the PNV justified their support for the first Aznar government:

Facing this situation, no country that aims to be in the single currency in 1999 can allow to rule without a budget, nor bear the situation of incertitude that will provoke in the international markets this situation. Even if we consider that this budget law ... can be improved, we think that political responsibility and the common good of all the citizens of this state demands an effort by political forces to give preference to this rather than partisan or strategic issues. (Zabalia, 1996, p. 1401)

Not only did the impending adoption of the euro foster this external support, but it also helped to create collusion between parties in their economic policies. In the words of Rodrigo Rato, then Minister of Economy:

we are all conscious that during the last year an important consensus has been adopted, an important convergence on political economy positions; on the one hand, a wide majority of this chamber support European integration since the process started in 1986 with the single market and then with the convergence produced by the European Union Treaty. (Rato, 1996, p. 1320)

Or the socialist speaker, Josep Borrell (1996), in the same way claimed that: 'I would like to be clear with the government that we agree on the macroeconomic objectives of inflation reduction and the deficit you are proposing. They were also our objectives. They are ambitious and difficult to obtain, but they are necessary' (p. 1333).

Therefore, some European policies, especially those that are more in the competence of the EU such as monetary policy, reduce governments' policy manoeuvrability and policy instruments, resulting in a decrease in decidability, especially with the main opposition party. The consequences are manifold. First, the reduction of policy options produces less variety in policy proposals and, as a consequence, a disempowerment of voters (Bartolini, 2005; Mair, 2000). Second, the collusion of mainstream parties leaves opposition to the EMU to policy-seeking parties, which may, however, play a role in governmental stability as external supporters (as in 1993, 1996 and 2004). Third, and taking into account the equally positive interiorisation of European opportunities by the two leading Spanish ethno-regionalist parties, we can conclude that the EMU's 
implementation had a consensus-building effect, facilitating otherwise difficult coalitions.

Who opposes or criticises European policies? In Spain, only the United Left presents negative and mixed conceptualisations of EU policies. We can observe how party ideology plays a role in the interiorisation and usages of Europe, with criticism based on party ideological reasons rather than on opposition to integration per se. As its leader claimed in the 1996 budget debate:

In other words, what is this debate useful for? Do we have decision powers after the vote if there are some criteria and deadlines of Maastricht convergence that influence this debate? Are we holding a debate of national sovereignty or are we holding the debate on something that comes from outside? Of course, he who is speaking to you in the name of the federal group, supports European integration. But, Hon. Members, if the convergence criteria mark the limits of this debate, the political force I am representing in this moment does not agree with the content or the instruments that the government is handling ... [w]e do it from an alternative philosophy, from another view of European integration. (Anguita, 1996, p. 1339)

The Italian case reinforces the idea that government status is important for understanding the mainly positive usages of Europe, while opposition depoliticises the European issue (Mair, 2000). For example, opposition parties do not use Europe for legitimising their positions in 80 per cent of investiture debates or 78 per cent of budget ones (Figure 3). However, we can observe a new and different trend where the Italian case differs from Spain. Whereas in Spain the importance of the European issue declined once the country joined the euro, in Italy the opposite is the case: during the period 2002-5 the importance of Europe remained almost the same as during the crucial years of the euro's creation (27 and 28 per cent, respectively, Figure 1). This could be due to the perceived negative consequences and limitations that the euro implied for Italy's economic performance. As a consequence, more parties, notably government parties, and even the main party of the centre-right, presented mixed or clearly negative positions and accounts of European policies. This is clear in our data, especially regarding budget debates. As Figure 2 shows, 10 per cent of their interventions in these debates consider Europe as a restriction for domestic action. In Figure 4, 14 per cent of their interventions present a mixed evaluation of EU policies, implying a growing perception of constraints and limitations. Why is this so?

Regarding the two largest parties, we can observe a clear difference between DS and Forza Italia (FI). The DS, together with the once predominant Democrazia Cristiana (DC), has a very positive conceptualisation of Europe, with no negative references to Europe in either budget or investiture debates. Therefore, in their evolution from the Italian Communist Party (PCI), the DS seems to have internalised Europe as an incentive for action and a legitimising factor, which helps to adopt unpopular decisions, especially for a centre-left party. As Morgando's (1996) budget debate intervention clearly shows, there is a link between 
Europe and domestic reform: 'If we want to consolidate our European prospective, we have to start a period of reforms that reshapes our welfare state' (p. 4).

Forza Italia has a more ambivalent position due to different factors, such as the perception of European constraints, their coalition partners (with contrasting and even very negative European positions), and their role in the implementation of the euro. The latter is especially relevant. Italy joined the euro under a centreleft coalition government that claimed this major political success as its own. However, it was the FI and the centre-right coalition that experienced the euro's policy limitations when they gained office in 2001, and their usages reflect this fact. ${ }^{8}$ In Gianfranco Conte's (FI) words:

We do not have to forget that, while we, as a government and as a country, are trying to follow the commitments adopted in the European Union, countries economically much stronger than us, such as France and Germany, have remarkable problems in maintaining the stability pact and many support that, eventually, something has to be revised. (Conte, 2001, p. 4)

Therefore, the strict measures of the Stability and Growth Pact posed a limitation on government, implying a more critical vision and a demand to reform it. In Guido Crosetto's (FI) words in the 2004 budget debate:

In fact it is undeniable that, after the adoption of the euro, the limits and the structural weakness of our economic system are now manifest with evidence never seen before. The Italian economy has not the instrument of competitive devaluation, strongly used in the past, precisely when the competition challenge, often disloyal, of some emerging countries is more obvious. (Crosetto, 2004, p. 43)

A second interesting aspect concerns the number and type of parties with negative perceptions of Europe - Alleanza Nazionale (AN), Lega Nord (LN) and Rifonazione Comunista (RC). The left party, RC, offers a good example of a negative position towards the EU and how ideology plays an important role in explaining that position. Since the euro's introduction, the EU is conceived in a negative way, ${ }^{9}$ and they criticise Europe on the same grounds as the Spanish Izquierda Unida (IU), showing the relevance of ideology and what has been labelled as the partisan model for explaining positions towards the EU (Bartolini, 2005, p. 321). As their speaker claimed in the 2001 Budget debate:

our amendments to this budget law tend to break down the European Stability Pact straightjacket, I think, against the proletariat, against the demands of the society for creating a macroeconomic context favouring a qualified expansive policy. This is the philosophy of our alternative project. (Russo Spena, 2001 p. 29)

In the case of the post-fascist $\mathrm{AN}$, the most interesting fact is the way the EU is constantly neglected. The importance and role of Europe in the AN's 
interventions is non-existent, with none of the 14 interventions presenting an assessment of European policies. The ethno-regionalist LN, in turn, offers a good example of an evolution from functional Europeanism to a soft or even hard Eurosceptic position (Conti \& Verzichelli, 2003). Until the mid-1990s, LN's support for Europe and the EMU was based on their idea that only Northern Italy could fulfil the euro criteria and, hence, a consensual division of Italy should be possible, with the rich north joining the euro without the south:

It is necessary to save southern Italy and to face the unemployment problem. Well, the only way to achieve this objective is to make a consensual split-up. In Padania we will use the euro as currency ... while our fellow European citizens of southern Italy will use the European single currency only some years later: beforehand they will have to improve their economic, productive and financial system. (Pagliarini, 1996, p. 5087)

This idea coincided with the party's goals, and thus the euro and the necessary reforms had the LN's complete support: 'The best laws approved by the parliament in recent years have been those that have taken in European directives and the great opportunities we have missed refer to the missed reception of European principles' (Pagliarini, 1996, p. 5084). However, once Italy as a country joined the euro, the incentives for supporting the EU disappeared, and so the LN did a complete U-turn in their European policy: ${ }^{10}$

Now the problem, joining the green grassland of the euro, is that of a global economy which, paradoxically, is in contradiction with an economic system based on small enterprises, yes, but also on a few big enterprises that, at least in the domestic market, were the masters; now, even these enterprises are too small in the global scenario, and the whole mechanism, on which the fragile Italian economy relied, risks entering into crisis. (Giorgetti, 1999, pp. 26-27)

Thus, it seems that the domestic consequences of Europe were much more problematic in the Italian case, especially in economic policy. This was reflected in the growing politicisation of the EU, not only among the opposition but also by governmental parties.

\section{Using Europe in Parliament: Some Conclusions}

The empirical analysis of the usages of Europe in parliamentary debates shows in line with the hypotheses - that the domestic context, notably governmental crisis and economic performance, is crucial for understanding the importance and usages of Europe. Hence, we have to take into account that the European context does not affect all countries or parties in the same way. Governmental status and position in the party system are also relevant. Parties in government and the two biggest parties in each country tend to present positive usages of Europe. Thus, criticism of the EU is left to opposition parties, where ideology 
plays a key role. The analysis has also displayed different indirect impacts of Europe, such as policy collusion in economic policy or the coalition-building effect in Spain during EMU's implementation.

What can we learn from the Spanish and Italian cases? Italy has shown how, in periods of economic and political crisis, the EU is more politicised. As a consequence, criticism of Europe and its negative impacts and reduction of policy alternatives was raised not only by the opposition but also by government parties, thus making the European issue more salient and problematic. For countries traditionally considered as pro-European who experience a period of domestic difficulties, especially regarding economic issues, the limitations posed by EU policies can break down the elite consensus towards integration. The depoliticisation of the European issue is not a feasible strategy because Eurosceptic parties will find arguments that resonate with the mood among the electorate. Additionally, government parties will suffer these limitations while in office and, hence, growing politicisation and increasing mixed or negative accounts may also arise among vote-seeking mainstream parties. Initially such criticism could be limited to certain specific policies, but once the issue is contested it could lead to growing disaffection towards the EU, both at the elite level and at the mass level. The same logic, but to a different degree and consequence, may apply to more Eurosceptic countries. The negative consequences of an already contested issue could imply a higher saliency of the EU, a strengthening of already existing Eurosceptic parties and positions and even a redefinition of the whole European project and the country's relation with the EU.

In both cases, however, national interests, opposed to European ones, are highlighted and the consequences can be manifold. These concluding remarks show, again, the importance of analysing not only the saliency of the European issue, but also the way parties (and citizens) internalise and use the European context in domestic political competition and in different national arenas. A better knowledge of how the EU and its policies affect each country and how it is politicised can provide a more insightful understanding of different domestic political processes with relevant consequences for European integration.

\section{Note on Author}

Fabio García Lupato is a Lecturer in the Department of Political Science and Administration I, University Complutense of Madrid, Spain; email: fabio.garcia@cps.ucm.es

\section{Notes}

1. In the Italian case we need to disentangle the different positions of individual parties that compete in elections under the same platform but have their own parliamentary groups.

2. The real gross domestic product growth rate shows that in the period 1992-2007, Spanish mean growth was 3.24 while Italy's was 1.41 . From 1999 to 2007 the mean rate was 3.74 and 1.46 for Spain and Italy, respectively. 
3. All translations from Italian and Spanish are by the author.

4. Furthermore, monetary policy, limited to inflation control, suited Spanish economic needs but penalised the Italian need for economic growth with low inflation.

5. The data on parties in government reflect their position, as all Spanish governments have been single-party governments. Both socialists (1982-96 and 2004-8) and conservatives (19962004) had an absolute majority or just a relative majority of seats.

6. CIU supported the socialist government during the period 1993-95, and CIU and PNV, with other minor parties, supported the PP government in the 1996-2000 legislature.

7. For example, as external supporters of the government they conceptualise Europe as a positive impact in investiture and budget debates ( 86 and 53 per cent, respectively), as an incentive for domestic action (86 and 67 per cent), or evaluate European policies positively, with 53 per cent accounts in budget debates (and no negative account) showing their positive stance on the EMU. As the PP and PSOE, they have almost no negative or mixed perception of the European impacts.

8. With 3.7 per cent of mixed impacts of Europe, 2.8 per cent of restriction for action and 4.6 per cent of mixed evaluations.

9. No positive references and 2.8 per cent of impact of Europe as a constraint and restriction for action and 3.7 per cent of negative evaluations of European policies.

10. For a contrasting view, see Chari, Iltanen, and Kritzinger (2004).

\section{References}

Anguita, J. (1996). Sesión Parlamentaria No. 31, pp. 1339-1344. Retrieved from http://www. congreso.es

Bartolini, S. (2005). Restructuring Europe: Centre-formation. State building and political structuring between the nation state and the EU. Oxford: Oxford University Press.

Berlusconi, S. (1998). Seduta 0426, pp. 81-85. Retrieved from http://www.camera.it

Borrell, J. (1996). Sesión Parlamentaria No. 31, pp. 1331-1338. Retrieved from http://www. congreso.es

Chari, R., Iltanen, S., \& Kritzinger, S. (2004). Examining and explaining the Northern League's 'U-turn' from Europe. Government and Opposition, 39, 423-450.

Conte, G. (2001). Seduta 72, pp. 2-8. Retrieved from http://www.camera.it

Conti, N., \& Verzichelli, L. (2003). The European dimension of political discourse in Italy: A longitudinal analysis of party preferences (1950-2001). CIRCaP Working Papers 12/2003.

Cotta, M. (2005). Élite politiche nazionali e costruzione della polity Europea. Il caso Italiano in prospettiva comparata. In M. Cotta, P. Isernia, \& L. Verzichelli (Eds.), L'Europa in Italia. Élite, opinione pubblica e decisioni (pp. 17-59). Bologna: Il Mulino.

Crosetto, G. (2004). Seduta 539, pp. 41-50. Retrieved from http://www.camera.it

D’Alema, M. (1998). Seduta 0647, pp. 5-13. Retrieved from http://www.camera.it

Garrett, G. (1998). Partisan politics in the global economy. Cambridge: Cambridge University Press.

Giorgetti, G. (1999). Seduta 635, pp. 26-30. Retrieved from http://www.camera.it

González, F. (1993). Sesión Parlamentaria No. 2, pp. 22-30. Retrieved from http://www.congreso.es

Hay, C., \& Rosamond, B. (2002). Globalisation, European integration and discursive construction of economic imperatives. Journal of European Public Policy, 9, 147-167.

Hay, C., \& Smith, N. (2005). Horses for courses? The political discourse of globalization and European integration. West European Politics, 28, 124-158.

Jacquot, S., \& Woll, C. (2003). Usage of European integration: Europeanisation from a sociological perspective. European Integration Online Papers (EIoP), 6. Retrieved from http://eiop.or.at/eiop/ texte/2003-012a.htm

Mair, P. (2000). The limited impact of Europe on national party systems. West European Politics, 23(4), 27-51.

Marks, G., Hooghe, L., Steenbergen, M. R., \& Bakker, R. (2007). Cross-validating data on party positioning on European integration. Electoral Studies, 26, 23-38.

Molins, J. (1995). Sesión Parlamentaria No. 178, pp. 9520-9523. Retrieved from http://www. congreso.es

Morgando, G. (1996). Seduta 86, pp. 5065-5069. Retrieved from http://www.camera.it

Pagliarini, G. (1996). Seduta 86, pp. 5084-5089. Retrieved from http://www.camera.it 
Pennings, P. (2006). An empirical analysis of the Europeanisation of national party manifestos, 19602003. European Union Politics, 7, 257-270.

Rato, R. (1996). Sesión Parlamentaria No. 31, pp. 1320-1331. Retrieved from http://www.congreso.es

Raunio, T. (2002). Why European integration increases leadership autonomy within political parties. Party Politics, 8, 405-422.

Russo Spena, G. (2001). Seduta 72, pp. 28-30. Retrieved from http://www.camera.it

Sitter, N. (2002). Opposing Europe: Euro-scepticism, opposition and party competition. SEI Working Paper No 56. Sussex: Sussex European Institute.

Zabalia, J. (1996). Sesión Parlamentaria No. 32, pp. 1401-1405. Retrieved from http://www. congreso.es 